Ann. Biol. anim. Bioch. Biophys., 1978, 18 (4), 1077-1082.

\title{
Short-term and cryopreservation of rainbow trout (Salmo gairdneri Richardson) sperm
}

\author{
par J. STOSS, S. BÜYÜKHATIPOGLU, W. HOLTZ \\ Institut für Tierzucht und Haustiergenetik \\ Albrecht-Thaer-Weg 1, 34 Göttingen, W. Germany.
}

Summary. This paper reports a series of experiments conducted to obtain data on shortterm preservation of trout semen. Using both motility of activated spermatozoa and fertilizing ability as criteria, it was found that rainbow trout semen, if not frozen, could be best stored if kept undiluted at $-2^{\circ} \mathrm{C}$ in an oxygen atmosphere. Stirring proved to be unfavorable. Antibiotics inhibited bacterial growth but had a detrimental effect on spermatozoa when added at levels as high as $9000 \mathrm{i}$. u. penicillin and $9000 \mu \mathrm{g}$ streptomycin $/ \mathrm{ml}$. Mixing milt from different males did not seem to effect storing ability. When taking these factors into account, rainbow trout semen could be stored for more than 3 weeks without loss of fertilizing ability.

In freezing semen from rainbow trout the best results were obtained when diluting one part semen with 1 or 3 parts of the following diluent mixture : $592 \mathrm{mg} \mathrm{NaCl}, 172 \mathrm{mg} \mathrm{KCl}$, $67.9 \mathrm{mg} \mathrm{CaCl}, 15.1 \mathrm{mg} \mathrm{MgSO}$ and $2420 \mathrm{mg}$ Tris made up to $100 \mathrm{ml}$ with water ; citric acid was added to bring the $\mathrm{pH}$ to 7.25 ; to this was added $400 \mathrm{mg}$ bovine serum albumin, $750 \mathrm{mg}$ Promine D-soybean protein and $12 \mathrm{ml}$ DMSO. Samples were frozen by pelleting on dry ice. The pellets were stored in liquid nitrogen and thawed in a 1 p. $100 \mathrm{NaHCO}_{3}-$ solution. Results were variable, covering a range of 2.6-80.3 p. 100 hatching (corrected for controls).

\section{Introduction.}

Attempts to store salmonid sperm either in a liquid or frozen state have been reported or reviewed mainly by Scheuring (1924), Barrett (1951), Henderson and Dewar (1959), Truscott et al. (1968) and Horton and Ott (1976), but up to now no fully satisfactory techniques have been produced.

\section{Material and methods.}

Milt from 2-3 year old male rainbow trout was collected into pre-cooled test tubes which were kept on water-ice for about $3 \mathrm{~h}$ before further processing.

\section{Preservation of liquid semen.}

We investigated the effect of dilution rate, temperature, gas atmosphere, addition of antibiotics, mixing of milt from several males and occasional stirring on the motility and fertility of rainbow trout semen stored in a liquid state. 
Experiment 1. - Samples of $1.5 \mathrm{ml}$ of either undiluted semen or semen diluted at a ratio of $1: 1$ or $1: 16$ with a buffered isotonic diluent resembling the inorganic composition of seminal plasma (Holtz ef al., 1976) were placed in open glass vials with a surface area of $3.14 \mathrm{~cm}^{2}$. The vials were placed in 1 I flasks (6 vials/flask) which were kept in total darkness either at $4^{\circ} \mathrm{C}$ or $20^{\circ} \mathrm{C}$. Twice daily the flasks were opened and gassed by one of a number of gasses (table 1). At the same time the samples were swirled gently to counteract sedimentation of spermatozoa. A small drop of semen from each vial was checked daily for motility (Holtz ef al., 1977).

Experiment 2. - Applying the same technique used in experiment 1, milt was kept at $4{ }^{\circ} \mathrm{C}$ under $\mathrm{O}_{2}$, at $-2{ }^{\circ} \mathrm{C}$ under air or at $-2{ }^{\circ} \mathrm{C}$ under $\mathrm{O}_{2}$ for a period of 23 days. Motility was judged as good, fair or poor depending on the minimal rates of motility which were 40,10 or 1 p. 100 respectively. There were 13 replicates per treatment.

Experiment 3. - Applying the same three treatments a fertility trial was conducted. Over a period of 23 days, semen was collected every other day and stored. Half of the strippings were stored individually; the other half were made into mixtures from 3 different males. On day 23, each sample was added to 200 freshly collected eggs. Two weeks later all eggs were cleared in an 8 p. 100 acetic acid solution and examined microscopically for embryonic development. There were 2 replicates per treatment.

Experiment 4. - To inhibit bacterial growth antibiotics were added to semen kept under storage conditions of $-2{ }^{\circ} \mathrm{C}$ under $\mathrm{O}_{2}$, checking for motility and fertility of spermatozoa. Penicillin was added at increasing levels up to 25000 i. u. per $\mathrm{ml}$ semen. Subsequently penicillin and streptomycin were added at a ratio of $1 \mathrm{i}$. u. : $1 \mu \mathrm{g}$ at levels of 0.40000 (4 replicates per treatment). Eventually a fertility trial was conducted comparing levels of $0,250,1000$ and $2000 \mathrm{i}$. u./ug. There were 8 replicates per treatment, 4 of which were left untouched while the other 4 were stirred gently Iwice daily. Half the samples were added to eggs after 10 days of storage and the other half after 16 days.

\section{Cryopreservation.}

For deep freezing rainbow trout semen a diluent was developed based on the composition of seminal plasma. The constituents of the diluent were : $592 \mathrm{mg} \mathrm{NaCl}$, $172 \mathrm{mg} \mathrm{KCl}, 68 \mathrm{mg} \mathrm{CaCl}_{2}, 15 \mathrm{mg} \mathrm{MgSO}, 2420 \mathrm{mg}$ Tris made up to $100 \mathrm{ml}$ with distilled water. Citric acid was added to adjust the $\mathrm{pH}$ to 7.25 before addition of $400 \mathrm{mg}$ bovine serum albumin, 500-1 $500 \mathrm{mg}$ Promine D (a soybean product of « Central Soya ») and $12 \mathrm{ml}$ dimethylsulfoxide (DMSO). Immediately after mixing semen and diluent at a ratio of $1: 1$ or $1: 3$, pellets (size $0.04 \mathrm{ml}$ ) were prepared on dry ice and stored in liquid nitrogen for 3-4 months. About 100 pellets were placed in $20 \mathrm{ml}$ of a 1 p. 100 $\mathrm{NaHCO}_{3}$-solution (Stein, 1975) at $1^{\circ} \mathrm{C}$. The resulting sperm suspension was immediately added to about 600 eggs which were then transferred to an incubator until the time of hatching. 


\section{Results and discussion.}

\section{Preservation of liquid semen.}

Experiment 1. - A temperature of $20^{\circ} \mathrm{C}$ was totally unsuited to the storage of trout semen. Thus the results presented in table 1 refer only to samples stored at $4^{\circ} \mathrm{C}$. They suggest that at that temperature dilution had an unfavourable effect on the survival rate and so did anaerobic conditions. Pure $\mathrm{O}_{2}$ proved to be superior to air or a $1: 1$ mixture of $\mathrm{N}_{2}$ and $\mathrm{O}_{2}$. This result is in good agreement with earlier findings by Scheuring (1924).

\section{TABLE 1}

Duration in days $(\bar{x} \pm s)$ of spermatozoan motility in trout milt stored at $4^{\circ} \mathrm{C}$ under different gas atmospheres at different dilution rates. The number of replicates is given in parenthesis

\begin{tabular}{|c|c|c|c|c|c|c|}
\hline \multirow[b]{2}{*}{ Dilution rate $a$} & \multicolumn{6}{|c|}{ Gas atmosphere } \\
\hline & Air & $\mathrm{O}_{2}$ & $\begin{array}{l}\mathrm{O}_{2} \pm \mathrm{N}_{2} \\
(1: 1)\end{array}$ & $\mathrm{N}_{2}$ & $\begin{array}{c}\mathrm{N}_{2}+\mathrm{H}_{2} \dashv-\mathrm{CO}_{2} \\
(8: 1: 1)\end{array}$ & $\mathrm{CO}_{2}$ \\
\hline $\begin{array}{c}\text { Undiluted } \\
1: 1 \\
1: 16\end{array}$ & $\begin{array}{cc}8.3 \pm 2.7(16) \\
1.0 \pm 0 & (6) \\
0 & (6)\end{array}$ & $\begin{array}{c}12.4 \pm 1.8(14) \\
{ }^{b}\end{array}$ & $\begin{array}{c}9.0 \pm 0(2) \\
-\end{array}$ & $\begin{array}{rr}3.6 \pm 1.3(10) \\
1.0 \pm 0 & (6) \\
0 & (6)\end{array}$ & $\begin{array}{l}0(4) \\
-\end{array}$ & $\begin{array}{l}0(6) \\
0(6) \\
0(6)\end{array}$ \\
\hline
\end{tabular}

a Semen : diluent ratio.

$b$ Not tested.

Experiment 2. - The results presented in figure 1 suggest that a gas atmosphere of $\mathrm{O}_{2}$ and storage temperature of $-2^{\circ} \mathrm{C}$ rendered the best results ; several samples retained a degree of motility up to 23 days.
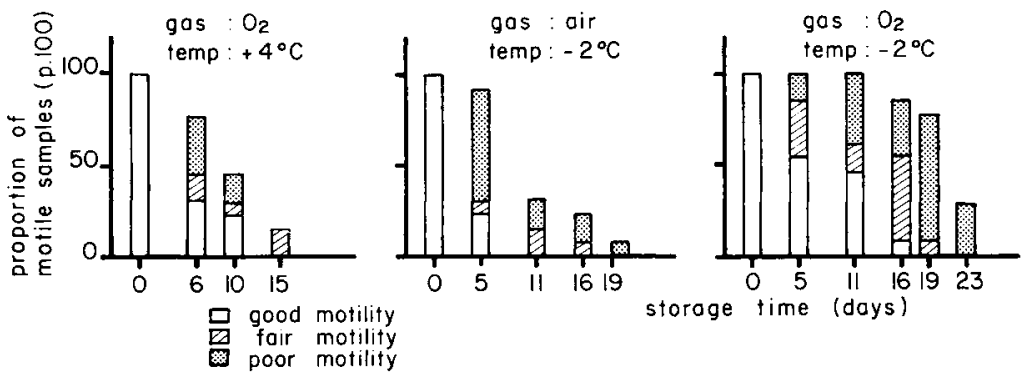

FIG. 1. - The proportion (p. 100) of samples with good (> 40 p. 100), fair (10-40 p. 100) or poor (1-10 p. 100) motility affer different storage times under either air or oxygen at temperatures of either $+4{ }^{\circ} \mathrm{C}$ or $-2^{\circ} \mathrm{C}$.

Experiment 3. - The results of the fertility trial are presented in figure 2. The fertilizing capacity of semen stored under $\mathrm{O}_{2}$ at $4{ }^{\circ} \mathrm{C}$ was retained for a period of 21 days. At $-2{ }^{\circ} \mathrm{C}$ under air it was 17 days, and at $-2{ }^{\circ} \mathrm{C}$ under $\mathrm{O}_{2}$ it had not subsided by the end of the experiment ( 23 days). While motility dropped to a low level during the 
more advanced stages of storage with the exception of a few individual samples fertilizing ability remained high right to the end. There appeared to be no effect of pooling semen samples from several males. A few samples had to be eliminated on account of decay, mainly due to progressively increasing numbers of bacteria.

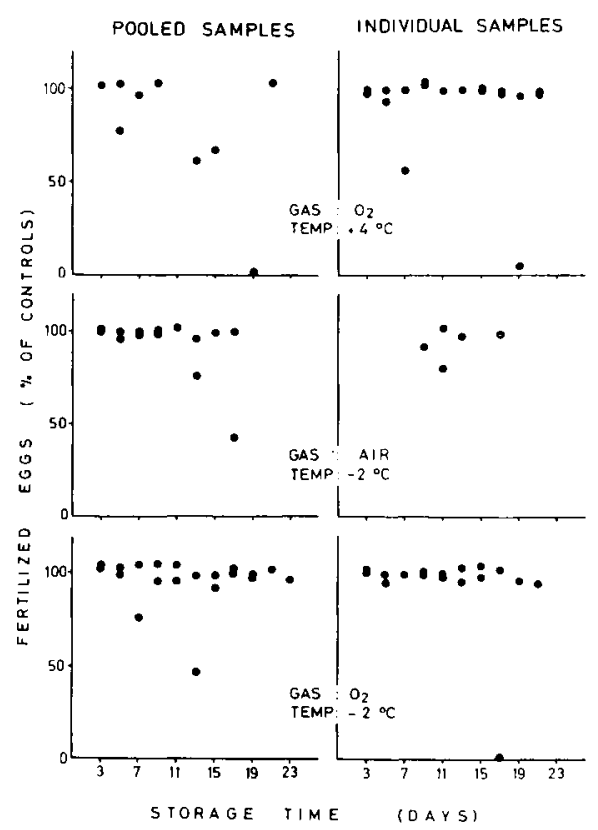

FIG. 2. - The proportion of eggs fertilized after different storage times of semen kept under air or oxygen ot temperatures of either $+4^{\circ} \mathrm{C}$ or $-2^{\circ} \mathrm{C}$. Each point represents one sample. Some samples had to be eliminated due to poor quality of eggs (second graph on right) or decay of semen due to bacterial growth.

Experiment 4. - During a 10-day storage period penicillin alone up to a level of $25000 \mathrm{i} . \mathrm{u} . / \mathrm{ml}$ semen had no effect on spermatozoan motility. When combining penicillin and streptomycin at a 1 i. $u .: 1 \mu \mathrm{g}$ ratio, motility was decreased as soon as quantities of $9000 \mathrm{i}$. u. respectively, $\mu \mathrm{g}$ were added. No difference was detected between

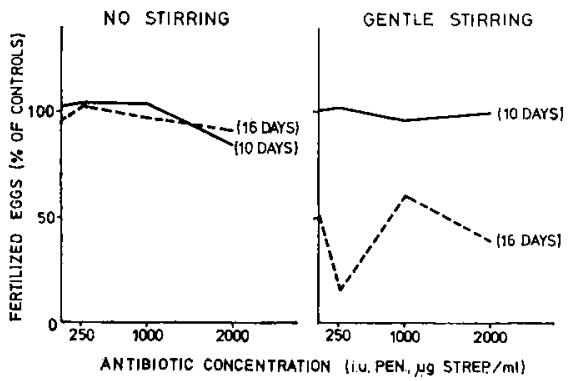

FIG. 3. - Proportion of fertilized eggs ofter 10 or 16 days of storage under oxygen at $-2{ }^{\circ} \mathrm{C}$ with the addition of different levels of antibiotics. Part of the samples were stirred gently twice daily. 
samples to which penicillin and streptomycin were added at levels of 500-6000 i. u., respectively, $\mu \mathrm{g}$ per $\mathrm{ml}$ semen. Beyond $9000 \mathrm{i}$. u., respectively, $\mu \mathrm{g}$, however, there was an immediate drop in spermatozoan motility. The lowest level tested was sufficient to prevent bacterial growth.

As illustrated in figure 3. the antibiotic levels tested did not effect the fertilizing ability of semen. Bacterial growth was inhibited in every case and no samples had to be eliminated. Repeated slight agitation of semen proved to be harmful. Fertility of samples stirred gently twice a day, while still good after 10 days, was significantly reduced after 16 days $(P<0.01)$.

\section{Cryopreservation.}

Since dilution rate did not seem to make a difference, samples in table 2 diluted at ratios of $1: 1$ and $1: 3$, were lumped together. This table presents the hatching results. The large variation of individual results was striking and leads to the conclusion that more research is needed. Our results compare favourably with those of other researchers (Bratanov and Dikov, 1960 ; Graybill and Horton, 1969 ; Ott and Horton, 1971a, b). Only Stein (1975) reports better success.

TABLE 2

The proportion of hatched eggs after fertilization with semen frozen after addition of a diluent with different levels of Promine-D and with fresh semen $(\bar{x} \pm s)$

\begin{tabular}{cccc}
\hline $\begin{array}{c}\text { Concentration of } \\
\text { Promine-D } \\
(\mathrm{mg} / 100 \mathrm{ml})\end{array}$ & $\begin{array}{c}\text { No. of } \\
\text { replicates }\end{array}$ & \multicolumn{2}{c}{ Fertilization rate (p. 100 eggs hatched) } \\
\cline { 3 - 4 } & 2 & Frozen semen & Fresh semen \\
\hline 0 & 3 & $12.7 \pm 9.5$ & $69.0 \pm 38.3$ \\
500 & 4 & $35.1 \pm 18.6$ & $94.7 \pm 5.0$ \\
750 & 3 & $45.0 \pm 22.4$ & $89.8 \pm 16.1$ \\
1000 & 1 & $21.4 \pm 29.4$ & $58.1 \pm 16.2$ \\
1500 & 3.5 & 96.0 \\
\hline
\end{tabular}

Some of the results appear encouraging, although the cause of their variation must be determined before the procedure can be considered suitable for practical application.

\section{Conclusions.}

It has been shown that rainbow trout milt in a liquid state can be stored up to periods of more than 3 weeks with practically no loss of fertilizing capacity, provided that it is kept at a temperature of $-2{ }^{\circ} \mathrm{C}$ under $\mathrm{O}_{2}$ and is not unduly agitated. The results obtained with cryopreserved milt are encouraging, although their considerable variation indicates the need for further study. 
Résumé. Une série d'expériences a été conduite sur la conservation à court terme du sperme de truite, utilisant la motilité et le pouvoir fécondant. Plusieurs paramètres ont été testés : température $\left(-2,4\right.$ et $\left.20^{\circ} \mathrm{C}\right)$, agitation, antibiotiques, oxygénation. L'agitation s'est révélée défavorable ; d'addition d'antibiotiques au sperme ( $9000 \mathrm{Ul}$ de pénicilline et $9000 \mu \mathrm{g}$ de streptomycine $/ \mathrm{ml}$ ) inhibe la croissance bactérienne, mais est défavorable à la conservation du pouvoir fécondant. Le cas le plus favorable à la conservation est le maintien du sperme à $-2^{\circ} \mathrm{C}$ sous oxygène ; dans ces conditions, le pouvoir fécondant a pu être conservé pendant 3 semaines. Le mélange de sperme de plusieurs mâles ne nuit pas à la conservation.

En ce qui concerne la congélation de la semence de truite Arc-en-ciel les meilleurs résultats ont été obtenus avec un mélange qui contenait une part de semence et 1 ou 3 parts de dilueur de la composition suivante : $592 \mathrm{mg}$ de $\mathrm{NaCl}, 172 \mathrm{mg}$ de $\mathrm{KCl}, 67,9 \mathrm{mg}$ de $\mathrm{CaCl}_{2}$, $15,1 \mathrm{mg}$ de $\mathrm{MgSO}_{4}$ et $2420 \mathrm{mg}$ de Tris. Ce mélange est ajusté à $100 \mathrm{ml}$ avec de l'eau et amené à $\mathrm{pH} 7,25$ avec de l'acide citrique. On ajoute ensuite $400 \mathrm{mg}$ de sérum albumine bovine, $750 \mathrm{mg}$ de Promine D (protéine de soja) ef $12 \mathrm{ml}$ de DMSO. Ensuite quelques gouttes du mélange sont déposées sur de la neige carbonique et les «boulettes » ainsi obtenues sont stockées dans l'azote liquide et dégelées dans une solution de $\mathrm{NaHCO}_{3}$ à 1 p. 100 avant insémination. Les résultats obtenus sont trés variables et se situent entre 2,6 et 80,3 p. 100 de taux d'éclosion.

\section{References}

BARRETT I., 1951. Fertility of salmonid eggs and sperm after storage. J. Fish. Res. Bd. Con., 8, $125-133$. BRATANOV K., DIKOV V., 1960. Über gewisse Eigenarten des Spermas bei Fischen. Landw. Zentralblatt, 7. 1301.

GRAYBILL J. R., HORTON H. F., 1969. Limited fertilization of steelhead trout eggs with cryo-preserved sperm. J. Fish. Res. Bd. Can., 26, 1400-1404.

HENDERSON N. E., DEWAR J. E., 1959. Short term storage of brook trout milt. Progr. Fish. Cult., 21, 169-171.

HOLTZ W., BÜYÜKHATIPOGLU S., STOSS J., OLDIGS B., LANGHOLZ H.-J., 1976. Preservation of trout spermatozoa for varying periods. FAO Techn. Conf. Aquaculfure, Kyoto, Japan, 26.52.6.1976, 1-3.

HOLTZ W., STOSS J., BÜYÜKHATIPOGLU S., 1977. Beobachtungen zur Aktivierbarkeit von Forellenspermatozoen mit Fruchtwasser, Bachwasser und destilliertem Wasser. Zuchthygiene, 12, 82-88.

HORTON H. F., OTT A. G., 1976. Cryopreservation of fish spermatozoa and ova. J. Fish. Res. Bd. Can., 33, 995-1000.

OTT A. G., HORTON H. F., 1971a. - Fertilization of chinook and coho salmon eggs with cryopreserved sperm. J. Fish. Res. Bd. Con., 28, 745-748.

OTT, A. G., HORTON H. F., 1971b. Fertilization of steelhead trout (Salmo gairdneri) eggs with cryopreserved sperm. J. Fish. Res. Bd. Can., 28, 1915-1918.

SCHEURING L., 1924. Biologische und physiologische Untersuchungen an Forellensperma. Arch. Hydrobiol. Suppl. 4, 181-318.

STEIN H., 1975. Spezielle Untersuchungen am Fischsperma unter besonderer Berücksichtigung der Spermakonservierung. Diss. T. U., München.

TRUSCOTT B., IDLER D. R., HOYLE R. J., FREEMAN H. C., 1968. Subzero preservation of Allantic salmon sperm. J. Fish. Res. Bd. Can., 25, 363-372. 